\title{
ONSHORE-OFFSHORE FACIES CHANGE OF NGRAYONG SANDSTONE IN MADURA AREA- INDONESIA
}

\author{
Sugeng Sapto Surjono ${ }^{1}$ and Mustafid Gunawan ${ }^{2}$ \\ ${ }^{1}$ Geological Engineering Department, Faculty of Engineering, Universitas Gadjah Mada, Yogyakarta \\ Indonesia, e-mail: sugengssurjono@ugm.ac.id \\ ${ }^{2}$ Directorate General Oil and Gas, Republic of Indonesia.
}

Received Date: November 1, 2017; Revised Date: December 6, 2018; Acceptance Date: December 7, 2018

\begin{abstract}
Ngrayong sandstone composes a siliciclastic reservoir that produces oil for more than a century in North East Java Basin of Indonesia. Clean sand facies makes the best reservoir in western part of the basin, onshore East Java Island. Meanwhile, sand quality decreases eastward to Madura Island. In Madura, rock gradually changes to be more calcareous and shaly, due to the change of depositional environment. In offshore of Madura, the depositional environment is still questionable. This study is aimed to reveal differences between onshore and offshore facies of Ngrayong sandstone in Madura as their distribution is not well known and oil potential of Madura Strait is not well identified. Study methods consisted of geological field work, well correlation, and petrophysical analysis from several well data. The results show that Ngrayong sandstone was deposited during Middle Miocene, composed by interbedding of thickly bedded sandstone and alternating thinly bedded sandstoneshale. The succession is commonly intercalated by mudstone and thinly bedded limestone. At Madura Island, Ngrayong sandstone overlies the Early-Middle Miocene Tawun Formation, which both represent the Megasequence (MS) 3 interval. Due to regional subsidence and transgression during Late Miocene, Ngrayong sandstone and other equivalent rocks were overlain by monotonous mudstone and calcareous sandstone of Wonocolo Formation. The Ngrayong sandstone is evenly distributed in whole surface area of Madura Island and it spreads further 25-50 Km to the south and 100-125 Km to eastern part of offshore Madura Strait. Sandstone distribution is roughly depleted from the gross thickness hundreds of meters in northern part to only few centimeters in southeast part of study area. The facies changes to be more calcareous to the east, while the southward facies is shaly due to a deeper depositional environment. Despite of facies changing into shales or carbonate facies, Ngrayong sandstone potential in offshore Madura Strait needs to be considered as upside potential due to its distribution is wider than initial estimation, and its petrology and petrophysic data support it as a clastic reservoir.
\end{abstract}

Keywords: Ngrayong sandstone, North East Java Basin, Madura, Facies change

\section{Introduction}

Madura Island is located in the northeast of Java Island, separated by Madura Strait (Figure 1). It is considered as the southern part of the North East Java Basin, a classic backarc basin situated on the southern margin of the stable Sunda Craton. It contains thousands of meters of Tertiary sedimentary sequence of siliciclastic rocks as well as carbonate rocks. The sequences having a good potential of hydrocarbon source rock and reservoir rock were reported in almost all stratigraphic levels from Eocene to Pliocene [1]. Those mainly are the Eocene Ngimbang clastic and carbonate, Kujung carbonate, Tuban carbonate and clastic, Miocene Ngrayong clastic, Wonocolo clastic and Late Miocene to recent carbonate sequences. To the south of Madura strait, the sediment represents the deep marine 
environment (Kendeng Zone), which then the basin is bounded by volcanic arc of Solo Zone (Figure 2).

Ngrayong sandstone, regarded as the most prolific reservoir in this basin, is extensively exposed along the northern part of East Java and almost the whole of Madura. The characteristics of sandstones are clean, quartzose, commonly fine to medium grained, well sorted, and frequently cross-bedded. It has produced an estimated $150 \mathrm{MMBO} ; 75 \%$ of basin production [2]. Ngrayong sandstones exhibit excellent reservoir properties with porosity greater than 35\% and permeability's up to 10 Darcy [3]. Besides, Ngrayong Formation also becomes the main target of hydrocarbon explorations in the North East Java Basin for more than a century mainly in the Cepu area of onshore North East Java Basin [1]. Moreover, it has been chosen as a candidate of Carbon Capture and Storage (CCS) pilot project due to its high porosity and shallow reservoir depth $[4,5,6]$.

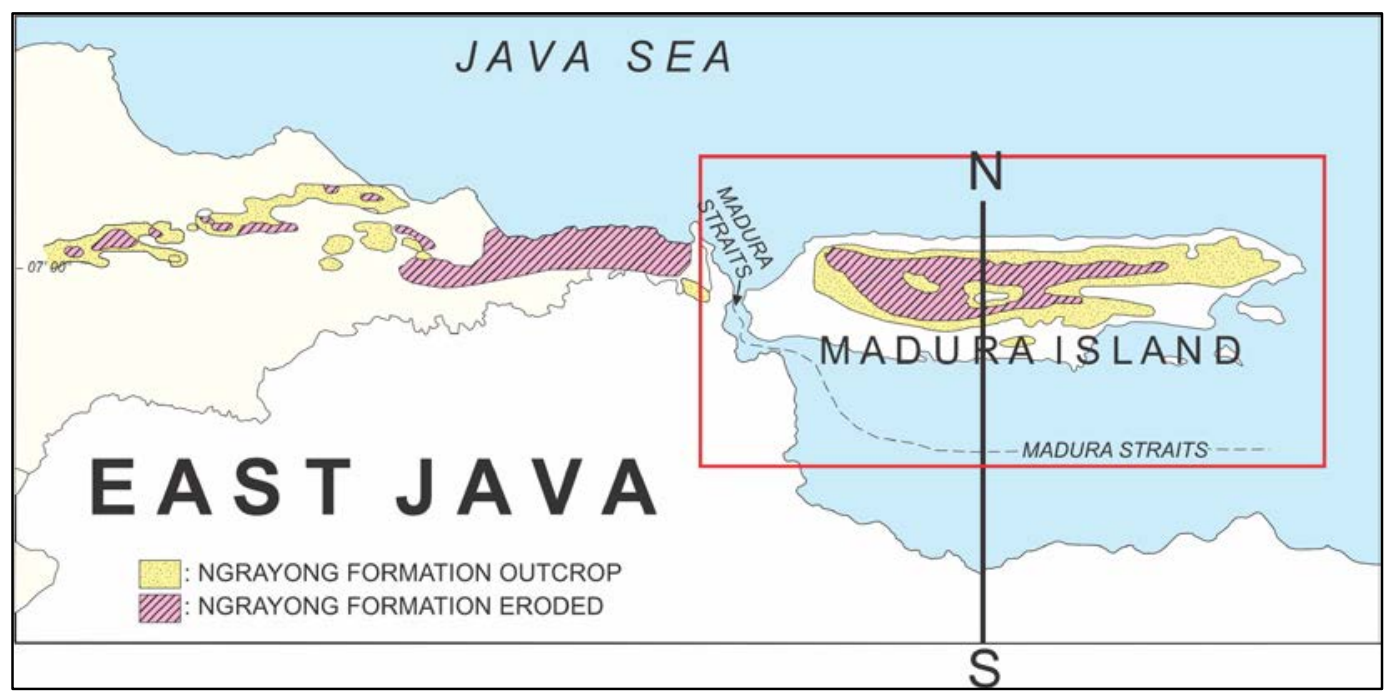

Figure 1. Madura area with recent outcrops distribution of Ngrayong sandstone (yellow) in Madura and East Java Island [2]. Study area is marked by red boxes, considered as the

Rembang-Madura Zone. It is generally located at the northern part of North East Java

Basin, and composed by succession of Neogene siliciclastic and carbonate sediments.

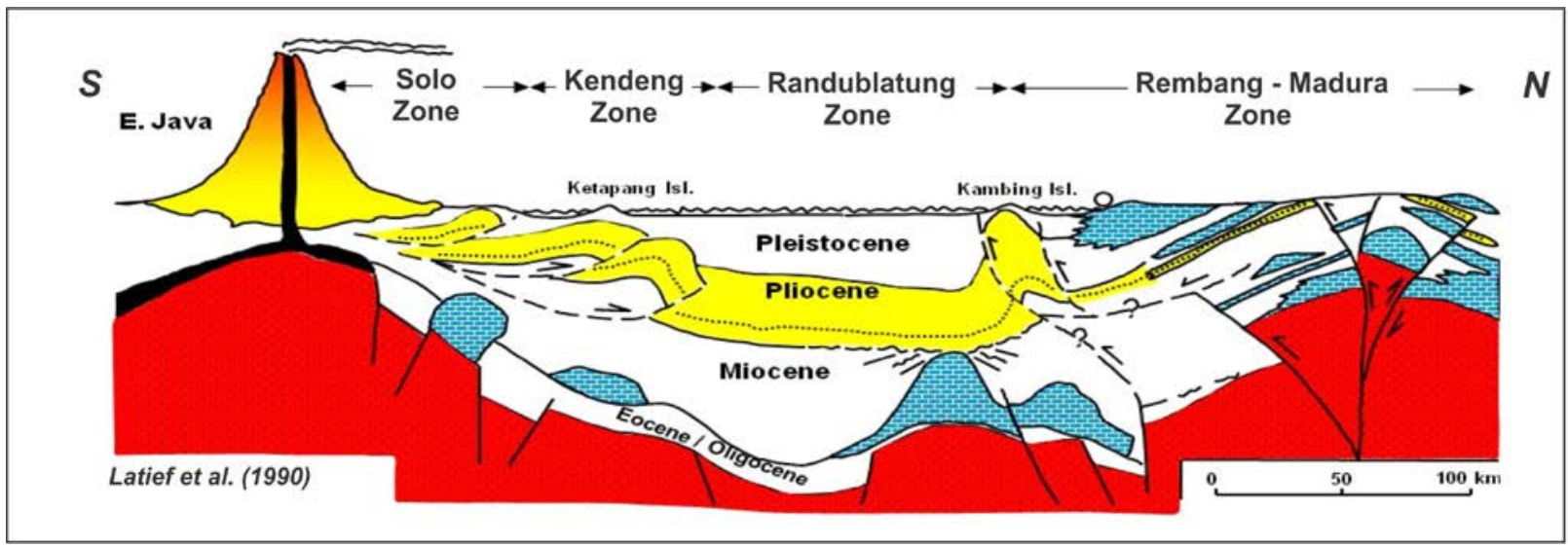

Figure 2. The North-South geological cross section showing physiographic zone of East Java [7]. The cross-section intersecting Madura Island can be seen in Figure 1. The shallow marine deposits of Rembang-Madura Zone gradually changed southward into the deep marine deposits of Kendeng-Randublatung Zone which is bounded by volcanic arc (Solo Zone) to the south. 
However, the sand contents of Ngrayong Formation decrease eastward, away from clastic supply [8]. The lithology gradually changes to be more calcareous and shaly, due to the change of depositional environment laterally from tidal flat in the relatively northern part to the deep marine in the southern part of basin $[9,10]$. In the offshore of Madura, the depositional environment of the Ngrayong sandstone is still questionable. Therefore, this study is aimed to reveal the differences between onshore and offshore facies change of Ngrayong sandstone because the distribution has not been well recognized and the potential in the Madura Strait also has not been well identified.

\section{Research Method}

This research combines both data obtained from Measured Section in Madura Island (onshore) with well data from Madura Strait (offshore). This study focuses on the Ngrayong sandstone interval, to reveal the sandstone's characteristics, which then steered in order to find out the quality and quantity as reservoir. There are 52 samples taken from onshore Madura area and 16 well data from onshore and southern part offshore of Madura including the well log data and the geological report were utilized in this study. The Ngrayong sandstones characteristics are identified by conducting measured stratigraphic of the outcrops observed from the three representative traverses of west, central, and east Madura Island. Petrological characteristics are approached form sequential outcrop samples analyses including granulometry, petrographic description, and well data observation including integration of well log, mud log, and cores. Petrophysical analysis is conducted to obtain the petrophysical properties of reservoir by using IP Software. The analysis includes reservoir thickness, net to gross ratio and porosity. The porosity and permeability are also measured from the outcrop samples in the laboratory with porosimeter and permeameter.

The changing of sandstone facies is determined based on the correlation between Measured Section at the surface and some well data from offshore Madura Strait. In order to get Ngrayong sandstone distribution in the sub-surface, extrapolation of well data is performed to predict the depletion of Ngrayong sandstone to the south and the east. Ngrayong sandstone distribution map with the depletion of thickness estimation to the south can be used as a reference of siliciclastic reservoir existence in sub-surface onshore Madura Strait.

\section{Regional Geology}

North East Java Basin is located on the southeast edge of the Sundaland craton which basements are Cretaceous and Early Tertiary mélange. It is considered as a back-arc basin which is bounded to the south by a young east-west trending Quaternary Java volcanic arc. Northern boundary is NE-SW trending Masalembo High, to the west is bounded by Karimunjawa Arch, and passes eastwards into the deepwater Lombok Basin. It covers an area of approximately 50,000 $\mathrm{km}^{2}[1,7]$. The major part of this basin at present forms the onshore of East and Central Java, and Madura Island, while the rest lies offshore below the Java Sea.

In terms of basin infilling, development of North East Java Basin sedimentation consists of 3 megasequences (MS) that are MS 1, MS 2, and MS 3 (Figure 3). The MS 1 and MS 2 are Paleogene Megasequences and MS 3 is a Neogene Megasequence [8]. MS 3 was initiated by collision between Australian Continent and eastern Indonesia contemporaneously with the continued driving of Australian Continent into the Sunda Trench and Banda arch. The sequence bounded by the top of Prupuh Formation at the bottom. The collision resulted thrusts contraction and inversion along the arc extends into 
East Java Sea in the Early Miocene. The occurrence of $675 \mathrm{~km}$ long left lateral fault zone of RMKS (Rembang-Madura-Kangean-Sakala) exist since Late Oligocene was a strong evidence of inversion [6,11]. MS 3 consists of widespread early to middle Miocene highstand progradation; transgressive late Miocene terminated by an early Pliocene lowstand; and high variability of late Plio-Pleistocene sedimentation [8]. The latest research in southeast Madura offshore identified the middle Miocene sediments developed into two sequences. Sequence- 1 consists of system tracts, such as LST, TST, and HST while sequence-2 comprises of TST and HST [12].

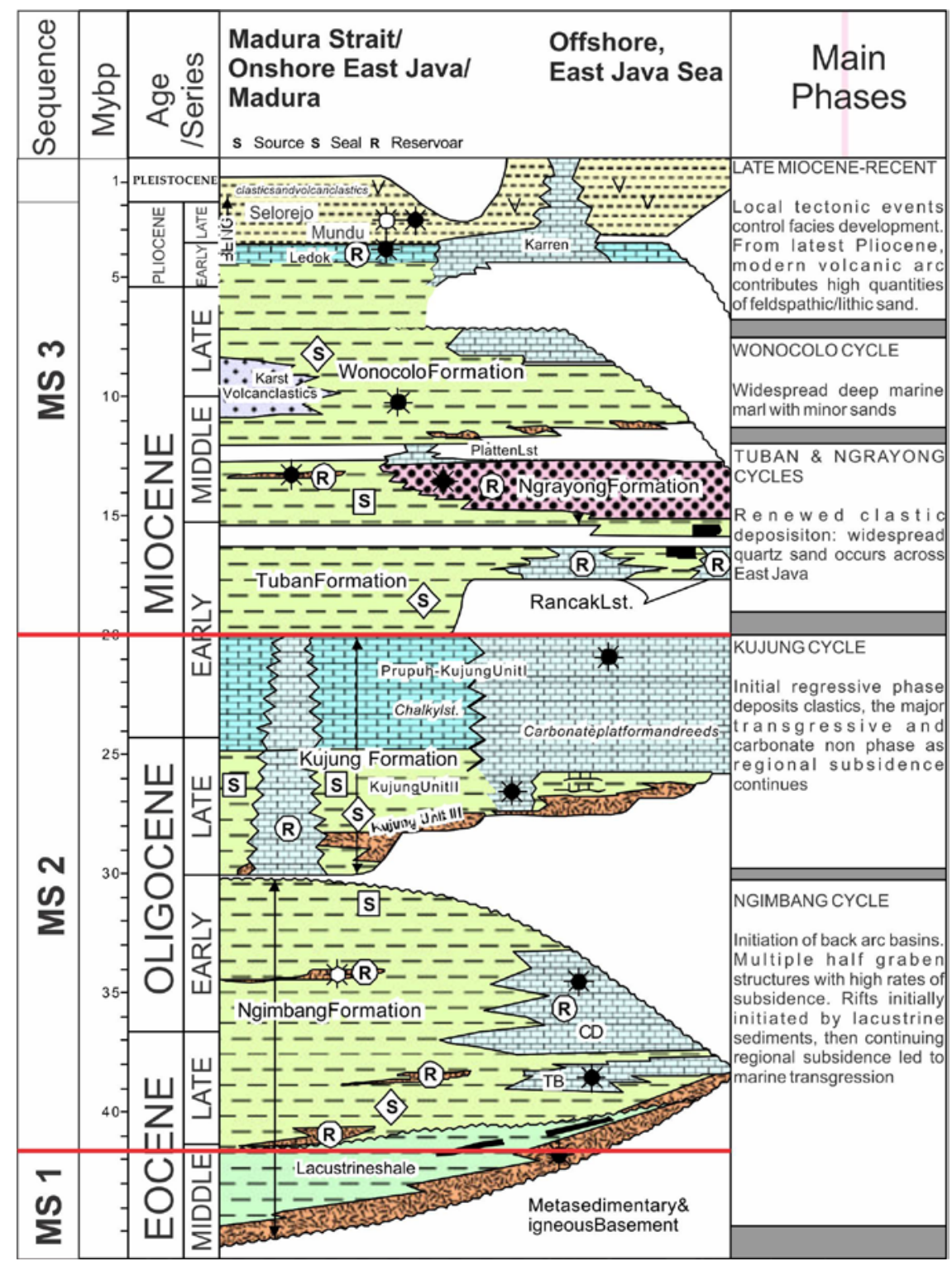

Figure 3. The regional stratigraphic column of North East Java Basin, with some modification $[1,3,8]$

The consequences of tectonic inversion that more effective during Late Oligocene to Middle Miocene caused depositional environment changes from carbonate to clastics environment. In the whole Java stratigraphic succession, local sequences and unconformities was marked with J10 - J120 represent Early Eocene to Pliocene epoch [10]. Paleogeography of study area during J70 and J80 (Late Oligocene to Early Miocene) was carbonate platform changed to deeper marine. At the beginning, the platform was slightly tilted and it makes 
much of reefs deposition was terminated. After this event, the platform subsided and resulted maximum marine transgression. As the consequences, transgressive clays were developed and become regional seal for Paleogene megasequences. This transgression passed up into highstand condition that produce clastic sequence, where Ngrayong sandstone was part of the succession. During Early to Middle Miocene (J90 sequence), depositional environment in the study area was supplied by the cratonic quartz dominated sand from central Kalimantan (Figure 5) north of basin to form thick sequence of Ngrayong Formation [10].

Ngrayong Formation consists of coarsening upward sequence with total thickness reach up to thousand feet $[2,5]$. Based on paleontological analysis, this formation indicates N9-N12 (Middle Miocene) in age [2]. The sediment covered the entire Java Sea and the margin of northern Java. This sediment was terminated in the Far East, because there were facies changes into carbonate sequence.

Mineralogically, Ngrayong sandstone is mature with more than $95 \%$ is composed by quartz arenite [10]. Lithological unit consists of sandstone with claystone/shale intercalation, marl, and orbitoidal limestone. The shale shows good fissility, in some places shows the occurrence of ripple marks. Clear, platy gypsum crystals are found between the layers. The sandstones are red to yellowish red in color, showing a soft sediment deformational structures and scattered vertical burrows of Ophiomorpha. The occurrence of ripple mark and gypsum crystals at the lower part of this formation indicates that this unit was at first deposited in an intertidal environment (red sandstones) then deepened into the middle shelf environment which produced orbitoidal (Cycloclypeous) limestone [14].

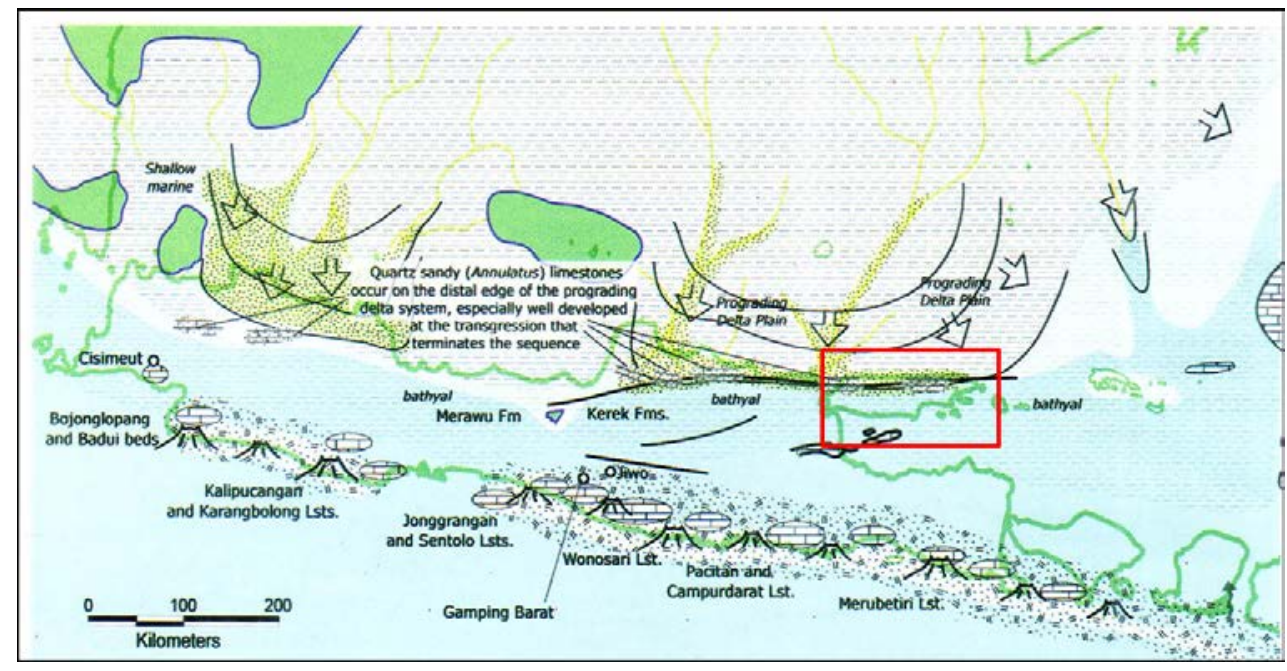

Figure 4. Paleogeography of study area and surrounding during J90 sequence (equivalent to early Middle Miocene) [13]. Ngrayong sandstones were deposited southward from central Kalimantan and reach present Madura Island (red box).

\section{Petroleum System}

\section{Source Rocks}

In Madura area, possible source rocks for generating hydrocarbon are non-marine to marginal marine of shales and coals of the middle - late Eocene Ngimbang/pre-Kujung, late Oligocene Lower Kujung, and the early Miocene Tuban Formations [15]. For all those source rocks, it is believed that around 95\% hydrocarbon is supplied by Eocene Ngimbang shales [1]. Total Organic Carbon (TOC) contents for each rock unit ranging from 1-4\% in shales and carbonaceous limestones and exceeds 40\% within coal layers [1]. 
Pre-Ngimbang Formation is classified as a fair - excellent source rock. It is proved by TOC value $0.96-8.03 \%$ [15]. Ngimbang Formation has good source rock proved by occurrences of good TOC (1.64\% - 5.67\%) on shale and coals ranging between $62-67 \%$ [9]. Source rock on this formation is classified into effective source rock because this source contains both of kerogen type II and III that would be a good source of hydrocarbons (oil and gas). Kujung Formation is classified as poor to moderate source rock, but on the deeper portion of the basin or trough, it has moderate to good source rock. Kujung II and Kujung III are composed by shale and coals containing terrestrial origin humic kerogen type. Generally, kerogen contained in this formation comes from terrestrial or higher plants (kerogen type III). Tuban Formation classified as potential source rock which has up to $2.25 \%$ TOC and up to $2.45 \%$ at onshore Madura [15].

\section{Reservoir rocks}

Reservoir on North East Java basin can be divided into sandstone reservoir and carbonate reservoir. In the northern Madura Platform, reservoir target for exploration are the siliciclastic Ngimbang and reef and reefal Carbonate of Kujung [1]. However, in the onshore East Java, Ngrayong sandstone become primary target for exploration since the Dutch colonialism at the end of $19^{\text {th }}$ and early $20^{\text {th }}$ centuries. In the Cepu area, up to 1990 's the Ngrayong sandstone produced $150 \mathrm{MMBO}$, considered as the $75 \%$ production of the basin [2]. Ngrayong sandstone at the outcrops have an excellent reservoir property with porosities greater than $35 \%$ and permeability up to 10 Darcy $[4,5,16,17]$.

Apart from those classic reservoir, turbiditic sandstone facies of Ledok-PaciranMundu Formations, Rancak Reefal Limestone and Paciran Limestone are also considered to have potential as the reservoir [3].

\section{Seal and Trapping Mechanism}

Primary seal in North East Java basin is thick shale facies of Tuban Formation for reservoir older than late Early Miocene. However, to preserve reservoir rocks of Middle-Late Miocene sandstone is provided by Late Miocene claystone equivalent to shale of Ledok Formation [2]. This study identifies that the overlying thick layer of claystone and mudstone, interpreted as Lidah sequence is also considered as good potential seal for Pliocene GL reservoir. The Lidah sequence was deposited in the latest Pliocene time.

As the North East Java Basin have endured multiple stages of faulting and inversion [1,11], structural traps are very common in this structurally complex area. Other trapping mechanism is reef build up and pinch out of clastic sediment in the flank of platform is also have potential for stratigraphic trap.

\section{Hydrocarbon Generation, Migration and Play}

Primary maturation of North East Java Basin was happened during the deposition of Tuban Formation. Furthermore, this formation consisting of shale could act as a seal when the migration from older source occurs [3]. Migration of hydrocarbon could be accommodated from active fault systems and also move up-dip toward the basin margin then to trap.

Hydrocarbon Play of North East Java Basin is defined into five cycles [1] that are the Ngimbang, Kujung, Tuban and Ngrayong, Wonocolo and Late Miocene-Recent cylces. In the study area, those cycles cannot be clearly defined due to slightly different variation in the sedimentary rocks succession. In the Madura Island toward southern offshore, the petroleum play consists of Paleogene, Pinnacle Reefs, and Ngrayong Formation/Pliocene Globigerinid Limestone Plays. 


\section{Characteristics of Ngrayong Sandstone}

Based on the geological cross section built from compilation of Measured Section (MS) in several traverses, the thickness of Ngrayong Formation in Madura Island is ranging from $300 \mathrm{~m}$ to $500 \mathrm{~m}$. The number is almost similar with the thickness of Ngrayong in East Java [2]. This formation is distributed widely in the middle part of Madura Island elongate with west east trending, covering Mt. Langgulang, Mt. Malang, Mt. Neleng, Mt. Panggungan, Mt. Rangga, Mt. Tenggeranyar, Sumbarlampok, and Bambungur. In onshore Madura, the Ngrayong Formation can be divided into Lower, Middle and Upper part of lithological unit. Lower part is dominantly composed by interbedded of calcareous sandstone lithofacies sequence with coarsening upward pattern. The middle part of Ngrayong Formation consists of interbedded of calcareous sandstone, massive sandstone, interbedded of fossiliferous limestone, claystone and interbedded of sandy limestone. The upper part of Ngrayong Formation consists of interbedded of sandy limestone, interbedded of flaser sandstone, interbedded of calcareous sandstone - calcareous claystone, siltstone - massive sandstone, intercalation of calcareous sandstone - calcareous claystone and interbedded of sandy limestone. Compared to Ngrayong Formation in East Java, the composition of sandstone in Madura Island is more calcareous, often interbedding with limestone. Under microscopic investigation, mostly mix siliciclastic-carbonate classification is more applicable [16].

The petrophysical properties based on outcrop sampling in the onshore Madura are good. Effective porosity of interbedded quartz sandstone is ranging from $31.88 \%$ up to $33.33 \%$, calcareous sandstone $23.72 \%$ with permeability value is about $168 \mathrm{mD}$ in quartz sandstone. Figure 5B shows outcrop of thick bedded quartz arenite (sandstone) in western Madura interbedding with coal layers. Granulometry analysis conducted for this sandstone is moderate to well sorted. Calculation to all measured section of Ngrayong Formation in Madura Island result for the ratio reservoir to the non-reservoir up to 60\% (N/G; net to gross ratio), indicate that succession of Ngrayong Formation has a good potential to be siliciclastic reservoir.

Sub-surface Ngrayong Formation in the onshore Madura is equivalent with the upper and lower OK Formation, the old terminology for formation with age of Early to Middle Miocene [18]. However, this terminology was widely adopted by many oil companies with no consistency in age and their correlation [13]. Based on M-4 well located in the onshore area, the Upper OK consists of fine-grained calcareous sandstone, calcareous siltstone, claystone and limestone. The Lower OK consists of claystone, calcareous siltstone with thin beds fossiliferous limestone intercalation and fine-grained calcareous sandstone (Figure 5A).

Apart from lithological identification, well data also utilize to petrophysical analyses including porosity value and reservoir and non-reservoir ratio (N/G). The petrophysical analysis of Ngrayong interval gives N/G ranging from $2-40 \%$ with porosity ranging from $13-27 \%$. To the south, the N/G value become decrease due to deeper depositional environment where shaly facies are more dominant. The lowest N/G value (2\%) is identified from M-6 well in around $50 \mathrm{~km}$ south of western part Madura Island (Figure 6A \& 6B) and interpreted as the outermost of Ngrayong distribution in the sub-surface offshore Madura Strait. The highest value for N/G is recorded from M-4 well in the southern coastal of Madura Island (Figure 6A) that penetrated 3155' of MS 3 interval with N/G up to $40 \%$. MS 3 includes the Selorejo, Mundu, Ledok, Wonocolo, Ngrayong, and Tuban Formations (Figure 3). The MS 3 is interval in the subsurface was identified from the marker of well report in each well. For the lowest average porosity result (13\%) is from M-17 well that contain calcareous sandstone and minor limestone. The highest average porosity result is 
from M-1 well with average porosity value $27 \%$ (Figure $6 \mathrm{~A}$ ). The correlation between the wells show that MS 3 interval is thinning to the south (Figure 6B).

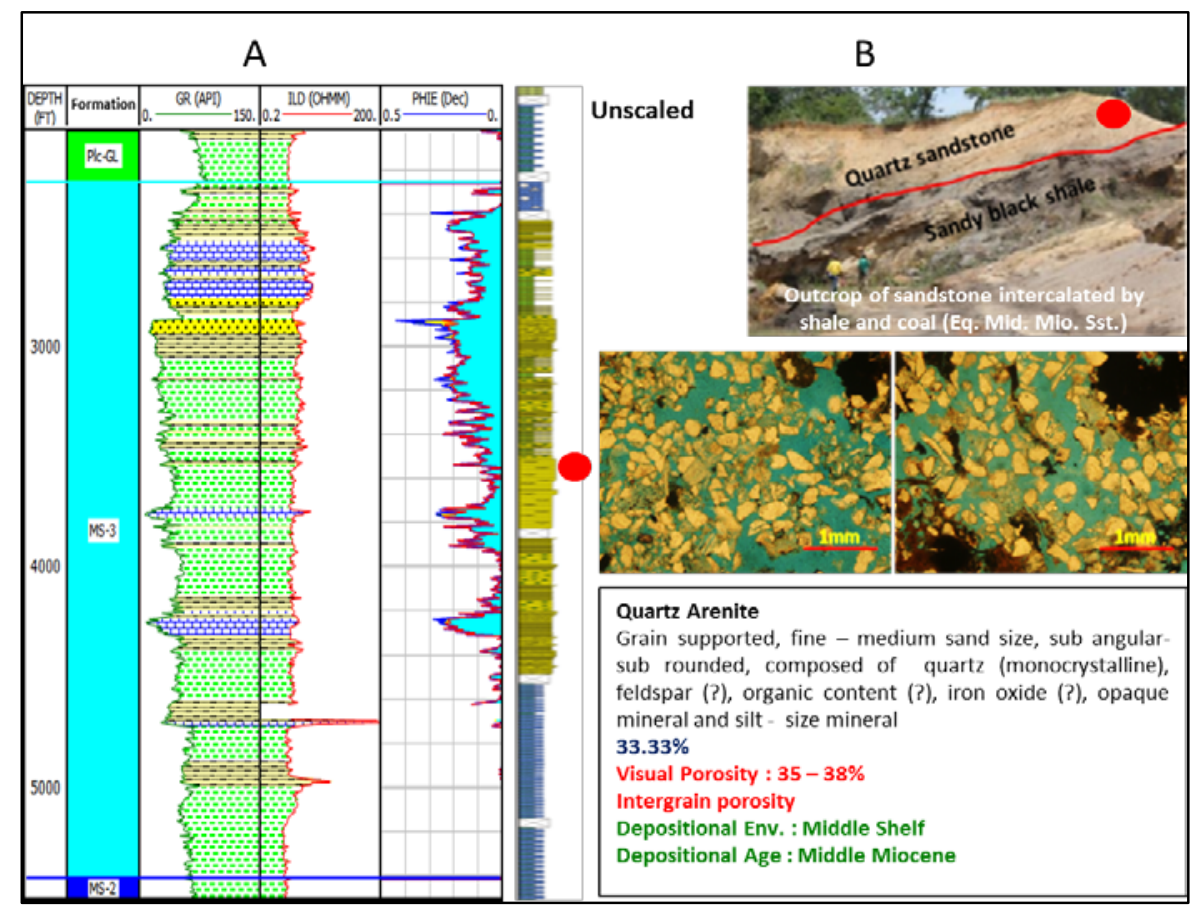

Figure 5. Characteristics and properties of Ngrayong Formation based on well data and outcrop. Red circle is the point location for sandstone petrographic analysis.

\section{Distribution and Facies Change}

Ngrayong Formation is easy to be determined in the field, due to their contrast lithology with the others. In Madura area, Ngrayong sandstone is distributed evenly in association with carbonate rocks formation. According to GRDC (Geological Research and Development Centre, Indonesia) map, the Ngrayong sandstone was mapped altogether with Tawun Formation in the map scale of 1:100,000. They were distributed evenly in the relatively central part of Madura Island to form inner ring of the island $[16,17,18]$. The distribution of Ngrayong sandstone is mostly controlled by anticlinorium of Madura, where in the central part it was already eroded to expose the older formation [2]

In term of lithofacies and properties, Ngrayong Formation in the surface from outcrop data can be correlated with those in the sub-surface from well data, which is indicated by their similarity in lithological pattern with well log (Figure 5A). Both surface and sub-surface lithological successions indicate that Ngrayong Formation is initiated with interbed of limestones, followed by the sandstones with shale intercalation where the sandshale ratio is decreasing upward, and finished by the interbed of limestone deposition. Both data indicate that further to the east and to the south this sandstone is changing in lithofacies and properties. Carbonate succession that overlies Ngrayong Formation becomes more dominant in the east of Madura Island. Several formations composed of carbonate rocks are more complex and complete in Madura Island including Pasean, Madura and Pamekasan. The research conducted in Puteran Island, east of Madura Island, shows that the petroleum system in this area is located within the Pliocence carbonate rocks of Madura Formation. [22]. All of those carbonate rocks equivalent with Ledok, Mundu, and Selorejo in the East Java that are mostly interbedding with siliciclastic rock based on regional stratigraphic column (Figure 3). 
The sandstone of Ngrayong interval is also present in several wells, mainly in the western part of Madura strait. Distribution of Ngrayong sandstone in the sub-surface is interpreted by extrapolation of well data recorded within this interval. The combination between surface geology and MS 2 isopach maps illustrates the paleogeography during the Miocene time in the study area, where Ngrayong sandstone interval was deposited. It is interpreted that the Miocene sand filled a low area from the north-northwest direction covering all Madura Island area and extended around $10 \mathrm{~km}$ to $25 \mathrm{~km}$ southward and around $75 \mathrm{~km}$ eastward from the recent south-east Madura coastline (Figure 7).

The depositional facies was changing from transitional environment to shallow or deeper environment. The depositional environment of Ngrayong Formation based on lithofacies distribution in onshore Madura area can be divided into three depositional units; they are coastal unit, upper shallow marine unit and low shallow marine unit $[9,17]$. However, some literature also said that the depositional environments are possible on the tidal flat system to the deeper subtidal carbonates associate with coastal dune. This evidence is based on the mixture of siliciclastic and carbonate materials in some intervals of Ngrayong reservoir that indicates a multi sources and processes during the deposition [16]. On the other hand, Ngrayong Formation is also interpreted to be deposited in the deep marine in southern distribution [10].

Based on the outcrop data, to the east of Madura Island, Ngrayong sandstone becomes decreasing in thickness and more calcareous in composition, although the depositional environment is just fluctuating in the inner to middle shelf (Figure 8). According to geological map published by GRDC, overlying Ngrayong Formation in the eastern Madura are the Bulu, Pasean and Madura Formations, where all of them are composed by carbonate rocks $[19,20,21]$. Based on the M-14 well data, to the south direction, facies of Ngrayong is also more calcareous. Further southward, generally Ngrayong sandstone change to more shaly because the depositional environment changes gradually from middle shelf, to outer shelf and deeper marine (Figure 9). The shale is characterized by the thick bedded shale with some lenticular structures and several bioturbation as biogenic sedimentary structures found on the top of beds.

Distribution of Ngrayong is truncated by the BD ridge in the southern part of Madura Strait. The BD ridge develops to the NE-SW direction, in parallel with Meratus pattern and it exists since the Paleogene [13]. Depocenter of the Ngrayong sandstone is possible in the south of study area adjacent to the BD ridge (Figure 9, index map).

\section{Conclusions}

The Ngrayong sandstone is evenly distributed in all surface area of Madura Island and it spreads further $25-50 \mathrm{Km}$ to the south and 100-125 Km to eastern part of offshore Madura Strait. This sandstone distribution is roughly depleted to the south and east from the gross thickness hundreds of meters in the northern part of Madura Island until only few centimeters left in the outer southeast part of the map. The lithology facies changes to be more calcareous to the east of Madura Island and offshore in the eastern side while the southward facies is more shaly due to a deeper depositional environment. In fact, the facies develop into carbonate which is known as OK Limestone/ Formation equivalent with Bulu Formation. Despite changing into shales or carbonate facies, Ngrayong sandstone's potential in offshore Madura Strait needs to be considered as upside potential due to its distribution which is wider than the initial estimation with continuous spreading, and its petrology and petrophysic characteristics which strongly support it as a clastic reservoir. 


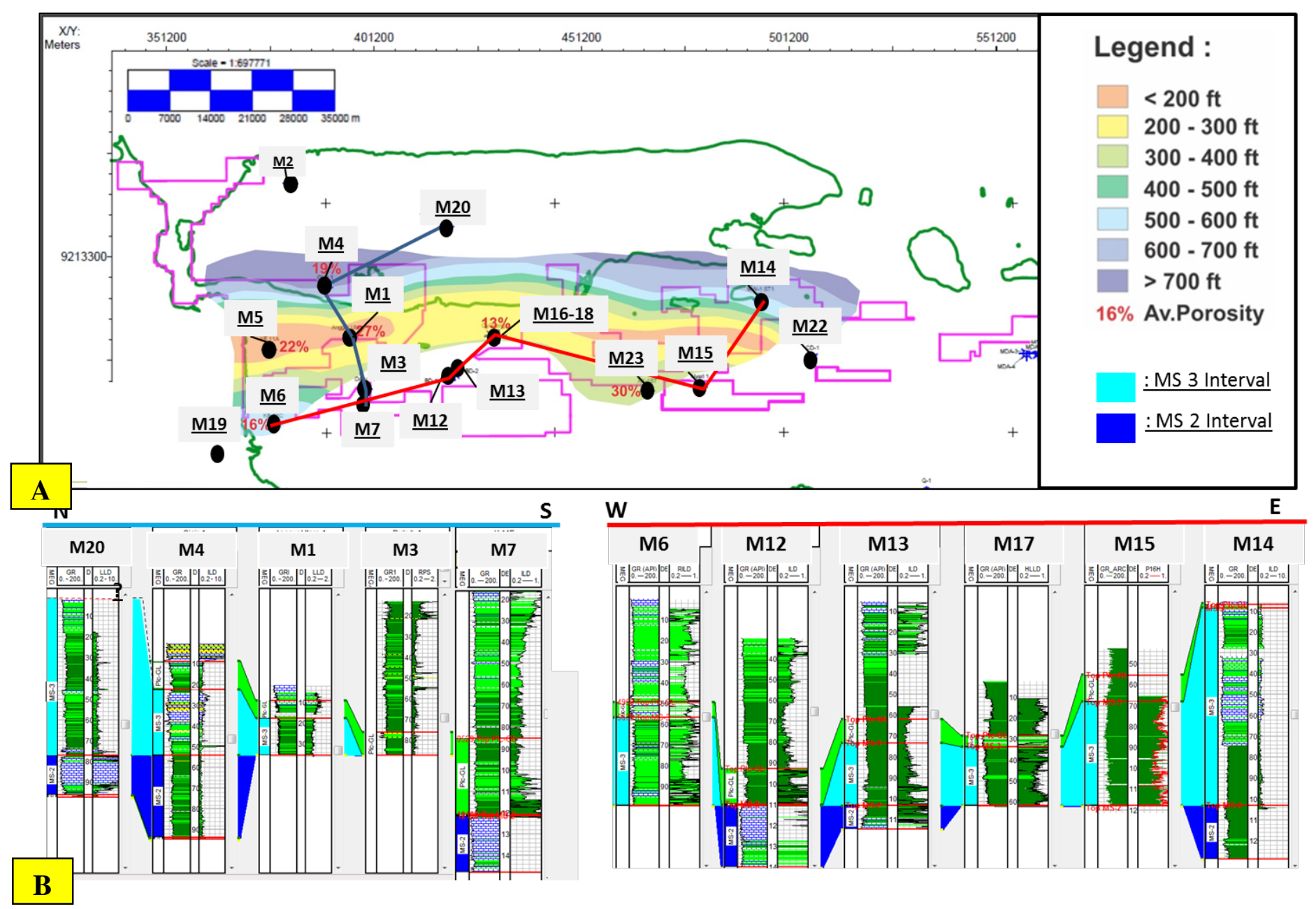

Figure 6. A The gross sand thickness and average porosity of MS 3 interval. The gross sand thickness map of MS3 showing the sand thickness is distributed evenly in W-E trend and it decreases to the south. N-S and E-W correlation of MS 3 intervals from several existing well data in the study area; B. The thickness of Ngrayong sandstone decreases to the south and it has a varying thickness from the west to the east. 


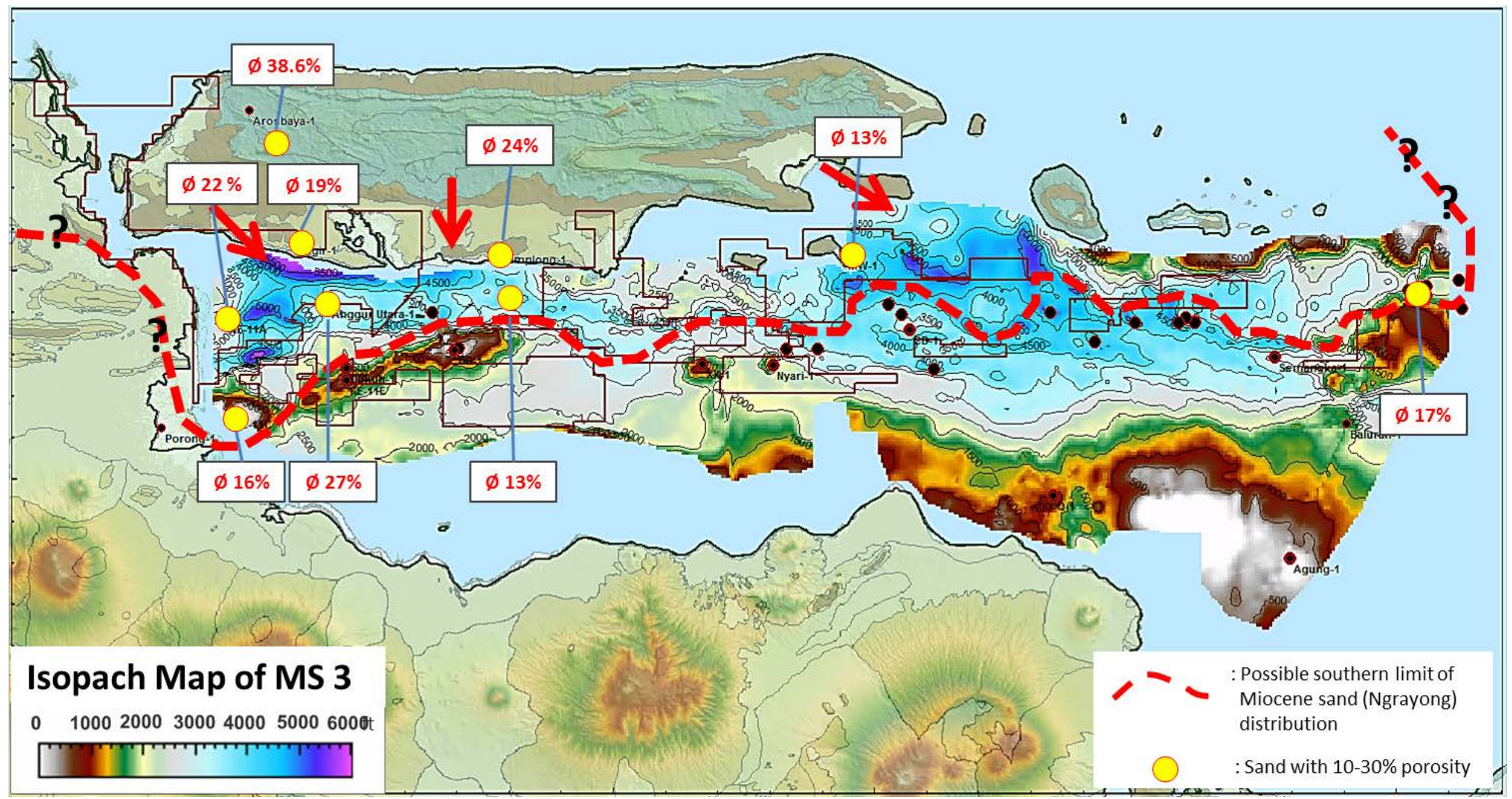

Figure 7. Ngrayong Sandstone distribution on the basis of sub-surface data in the Madura Island and the Offshore Madura Strait. The isopach map showing the thickness of sequence MS 3 


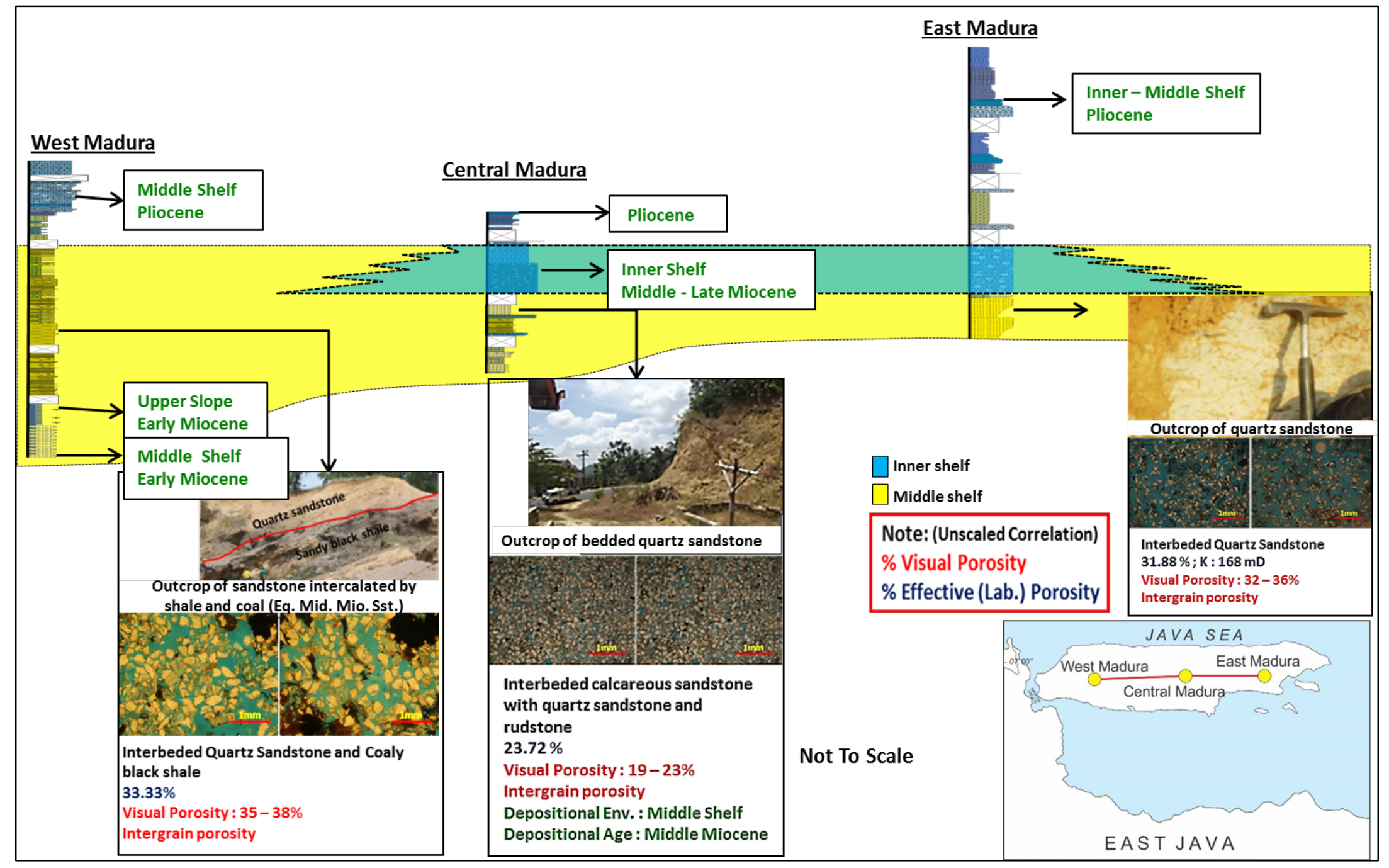

Figure 8. West-East correlation of Ngrayong sandstone from surface data in Madura Island. Rock facies change from sandstone-dominant to more calcareous and thinner succession eastward 


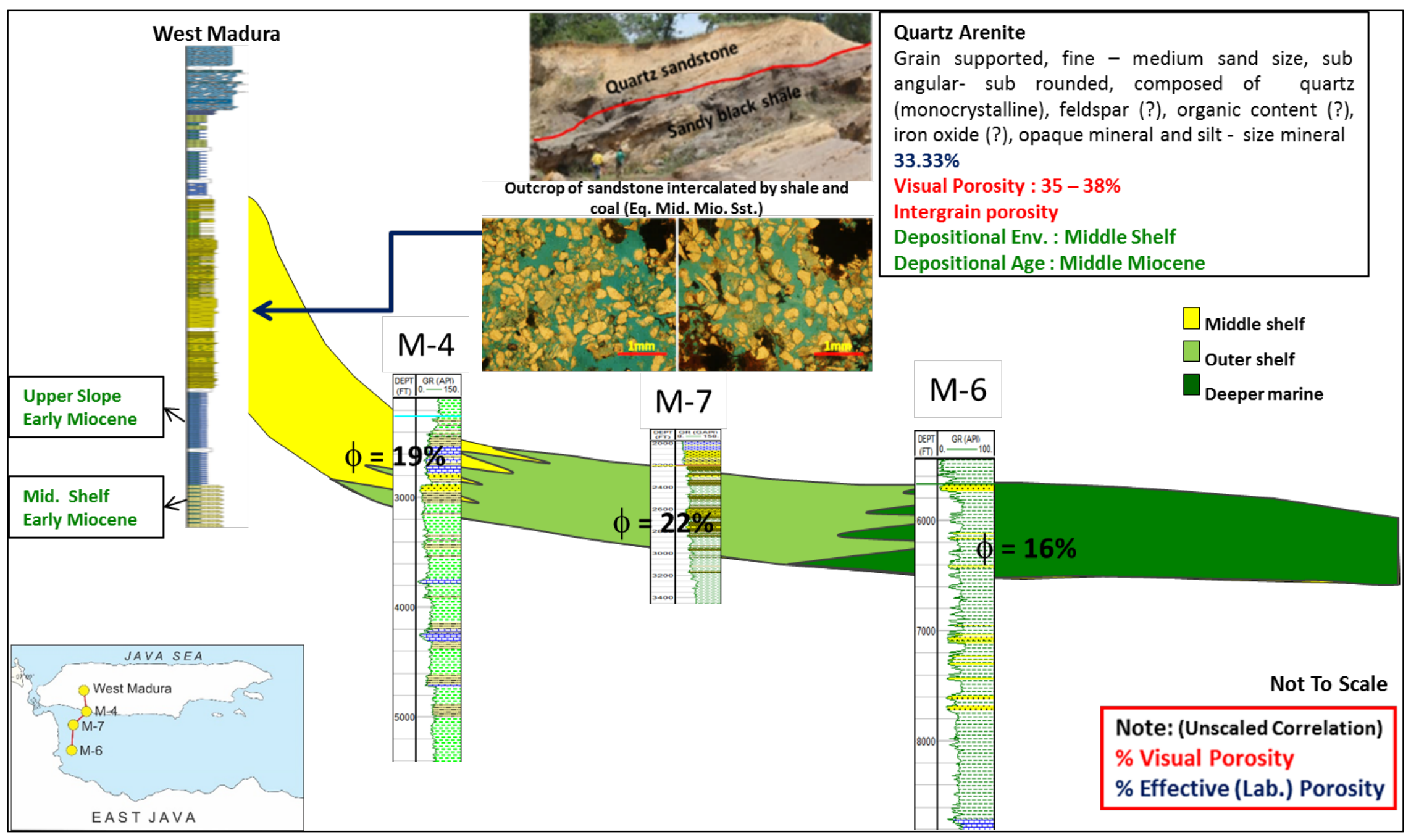

Figure 9. North-south correlation represents onshore-offshore and surface-sub-surface correlation of Ngrayong sandstone in Madura Island to offshore Madura Strait, indicates a facies change from sandstone-dominant to shale-dominant with the depositional environment gradually changes from middle shelf to deeper marine. 


\section{Acknowledgement}

Our gratitude goes to Directorate General Oil and Gas Republic of Indonesia for their permission in using the sub-surface data in offshore Madura. Our appreciation also goes to the research assistants in the Sedimentology Laboratory, Geological Engineering Department, Faculty of Engineering, Universitas Gadjah Mada for their help during the fieldwork and the manuscript preparation.

\section{References}

[1] R. Mudjiono, and G.E. Pireno, "Exploration of the North Madura Platform, Offshore East Java, Indonesia,” Paper presented at Indonesian Petroleum Association $28^{\text {th }}$ Annual Convention, Indonesian Petroleum Association, Jakarta, Indonesia, 2001, doi: 10.29118/ipa.980.707

[2] W. Ardhana, "A Depositional Model for the Early Middle Miocene Ngrayong Formation and Implications for Exploration in the East Java Basin," Paper presented at Indonesian Petroleum Association $22^{\text {nd }}$ Annual Convention, Jakarta, Indonesia, 1993, doi: 10.29118/ipa.845.395.443

[3] Patra Nusa Data, Indonesian Basin Summaries (IBS): North East Java Sea Basin and North East Java Basin, PT. Patra Nusa Data, Jakarta, Indonesia, pp. 69-94, 2006.

[4] K. Kitamura, Y. Yamada, K. Onishi, T. Tsuji, S. Chiyonobu, B. Sapiie, A. Bahar, H. Danio, A. Muhammad, A. Erdi, V.M. Sari, T. Matsuoka, and W. Gunawan, "Potential evaluation of $\mathrm{CO}_{2}$ reservoir using the measured petrophysical parameter of rock samples in the Gundih CCS Project, Indonesia,” Energy Procedia, Vol. 63, pp. 49654970, 2014. doi: 10.1016/j.egypro.2014.11.525

[5] T. Tsuji, T. Matsuoka, W.G.A. Kadir, M. Hato, T, Takahashi, M.R. Sule, K. Kitamura, Y. Yamada, K. Onishi, D.S. Widarto, R.I. Sebayang, A. Prasetyo, A. Priyono, T. Ariadji, B. Sapiie, E. Widianto, and A.R. Asikin, "Reservoir characterization for site selection in the Gundih CCS project, Indonesia," Energy Procedia, Vol. 63, pp. 63356343, 2014. doi: 10.1016/j.egypro.2014.11.666

[6] B. Sapiie, H. Danio, A. Priyono, A.R. Asikin, D.S. Widarto, E. Widianto, and T. Tsuji., "Geological characteristic and fault stability of the Gundih CCS pilot project at central Java, Indonesia," Paper presented at The $12^{\text {th }}$ SEGJ International Symposium, Society of Exploration Geophysicists of Japan (SEGJ), Tokyo, Japan, 2015, doi: 10.1190/segj122015-029

[7] R. Latief, P. May, and A. Suseno, Indonesian Petroleum Association Post Convention Field Trip-Madura Island Guide Book, Indonesian Petroleum Association (IPA), Jakarta, Indonesia, 1990.

[8] P.J.E. Bransden, and S. J. Matthews, "Structural and stratigraphic evolution of the East Java Sea, Indonesia,” Paper presented at Indonesian Petroleum Association $21^{\text {st }}$ Annual Convention, Jakarta, Indonesia, 1992, doi: 10.29118/ipa.674.417.453

[9] M.A.C. Endharto, "The tidal flat-shelf depositional system of Ngrayong sandstone in western part of the Madura," Paper presented at Indonesian Association Geologist $33^{\text {rd }}$ Annual Convention and Exhibition, Indonesian Association of Geologists (IAGI), Jakarta, Indonesia, 2004.

[10] W. Ardhana, P. Lunt, and G.E. Burgon, "The deep marine sand facies of the Ngrayong formation in the Tuban Block, East Java Basin," Paper presented at Indonesian Petroleum Association Clastic Core Workshop, Jakarta, Indonesia, 1993, doi: 10.29118/ipa.2513.117

[11] A.H. Satyana, E. Erwanto, and C. Prasetyadi, "Rembang-Madura-Kangean-Sakala (RMKS) Fault Zone, East Java Basin: The origin and nature of a geologic border,” In: 
H. Panggabean, and K. Budiono, eds., The IAGI 33 ${ }^{\text {rd }}$ Annual Convention, IAGI, Bandung, Indonesia, pp. 1-23, 2004.

[12] Y. Yuniardi, "Seismic and sequence analysis of middle to late Miocene deposits of Northeast Java Basin,” Indonesian Journal on Geoscience, Vol. 2, No. 2, pp. 101-110, 2015.

[13] P. Lunt, The Sedimentary Geology of Java, Indonesian Petroleum Association, Jakarta, Indonesia, 2013.

[14] G. Burgon, P. Lunt and T. Allan, IPA Fieldtrip to Eastern Java, Indonesian Petroleum Association, Jakarta, Indonesia, 2002.

[15] A.H. Satyana, and M.E.M. Purwaningsih, "Geochemistry of the East Java Basin: New Observations on Oil Grouping Genetic Gas Types and Trends of Hydrocarbon Habitats," Paper presented at Indonesian Petroleum Association $29^{\text {th }}$ Annual Convention, Indonesian Petroleum Association, Jakarta, Indonesia, 2003, doi: 10.29118/IPA.831.03.G.021

[16] S.S. Surjono, and A.M. Putranto, "Dynamic Sedimentation of Ngrayong and Bulu Formations in Sampang Area, Western Madura, Indonesia,” In: Proceedings of the $4^{\text {th }}$ Regional Conference on Geological Engineering: Research-based Education in Geological and Geo-resources Engineering for Sustainable Development in ASEAN Region, Vientiane, Laos, pp. 19-27, 2012.

[17] P. Htwe, S.S. Surjono, D.H. Amijaya, and K. Sasaki, “Depositional model of Ngrayong formation in Madura area, North East Java basin, Indonesia," Journal of Southeast Asian Applied Geology, Vol. 7, No. 2, pp. 49-58, 2015.

[18] H. Doust, and R.A. Noble, "Petroleum System of Indonesia," Marine and Petroleum Geology, Vol. 25, pp. 103-129, 2008.

[19] Sukardi, Geologial Map of Surabaya and Sapulu Sheets, Jawa, 1:100,000, Bandung, Indonesia: GRDC (Geological Research and Development Centre), 1992.

[20] S. Azis, Sutrisno, Y. Noya, and K Brata, Geological Map of Tanjungbumi and Pamekasan, 1:100,000, Bandung, Indonesia: GRDC (Geological Research and Development Centre), 1992.

[21] R.I. Situmorang, D.A. Agustianto, and M. Suparman, Geological Map of WaruSumenep Sheet, 1:100,000, Bandung, Indonesia: GRDC (Geological Research and Development Centre), 1992.

[22] A.S.P. Pakpahan, J. Jyalita, and S.S. Surjono, "Sedimentology and Characteristics of Pliocene Shallow Marine Carbonate as Reservoir Alternative Based on Outcrop Analogue in Madura and Puteran Island, Northeast Java Basin,” Paper presented at AAPG/SEG International Conference \& Exhibition, Melbourne, Australia, 2015, doi: 10.1190/ice2015-2211010 